\title{
Effects of nandrolone decanoate on the viability of muscle satellite cells during the differentiation process
}

\author{
Influência do anabolizante decanoato de nandrolona sobre a \\ viabilidade de células satélites musculares em processo de diferenciação \\ Influencia del anabolizante decanoato de nandrolona en la \\ viabilidad de las células satélites musculares en el proceso de diferenciación
}

Beatriz Guimaraes Ribeiro', Kristianne Porta Santos Fernandes ${ }^{1,2}$, Mikaele Tavares Silva ${ }^{3}$, Simone Oliveira Sierra', Sandra Kalil Bussadori ${ }^{1,2}$, Raquel Agnelli Mesquita-Ferrari, ${ }^{1,2}$

\begin{abstract}
I Studies indicate that the anabolic nandroIone decanoate (Deca-Durabolin ${ }^{\oplus}$ ) can modulate cell cycle regulation, but little is known about its effects on muscle cells. Anabolic steroids are used, especially by athletes, to improve muscle mass and performance in the practice of exercises. The aim of this study was to evaluate the effect of the anabolic Deca-Durabolin ${ }^{\circledR}$ on the proliferation of skeletal muscle precursor cells C2C12. Cells were grown in Dulbecco's Modified Eagle Medium (DMEM), being supplemented with $10 \%$ Fetal Bovine Serum (FBS) and subjected to differentiation by the addition of $2 \%$ horse serum. They were incubated with anabolic at concentrations of 5, 10, 25 and $50 \mu \mathrm{M}$. The groups that received no anabolic or vehicle served as controls. The viability (proliferation) was evaluated by the MTT method (3-[4,5-Dimethylthiazol-2yl]2,5-diphenyltetrazolium bromide; Thiazolyl blue) after one, three and five days of incubation. Three independent experiments were performed in each of the mentioned conditions, and the results were submitted to statistical analysis with significance level of $p \leq 0.05$ (ANOVA/Dunnett). Results showed no difference in viability between muscle cells treated with anabolic and the control cultures in all parameters. In conclusion, nandrolone, at the used concentrations, was not able to alter the viability of muscle C2C12 satellite cells.
\end{abstract}

Keywords | Anabolic; Athletes; Muscle Cells; Nandrolone; Cell Proliferation; Cell Differentiation.

RESUMO I Os anabolizantes são utilizados, especialmente por atletas, com o intuito de aumento da massa muscular e melhora do desempenho. Este estudo objetivou avaliar o efeito do anabolizante Deca-Durabolin ${ }^{\circledR}$ sobre a viabilidade (proliferação) de células satélites musculares C2C12 induzidas à diferenciação, mimetizando o processo de reparo após lesão. As células foram cultivadas em Meio Eagle Modificado por Dulbecco (DMEM) suplementado com 10\% de Soro Fetal Bovino (SFB) e submetidas à diferenciação pela adição de $2 \%$ de soro de cavalo e concomitantemente incubadas com o anabolizante nas concentrações de 5, 10, 25 e $50 \mu \mathrm{M}$. Os grupos que não receberam o anabolizante nem o veículo serviram como controle. A viabilidade (proliferação) foi avaliada após um, três e cinco dias, utilizando o método de MTT (3-[4,5-dimetiltriazol-2-il]-2,5 difeniltetrazólio). Foram realizados três experimentos independentes, em cada condição citada, e os resultados submetidos à análise estatística com nível de significância de $\mathrm{p} \leq 0,05 \%$ (ANOVA/Dunnet). Os resultados permitiram verificar que não houve diferença na viabilidade entre células musculares tratadas com o anabolizante e induzidas à diferenciação e as culturas

Study conducted at the Research of Celll and Mollecular Biology of Universidade Nove de Julho (UNINOVE) - São Paulo (SP), Brazil. PPostgraduate Program in Rehabilitation Sciences at UNINOVE - São Paulo (SP), Brazil.

${ }^{2}$ Postgraduate Program in Biophotonics Applied to Health Sciences at UNINOVE - São Paulo (SP), Brazil.

${ }^{3}$ Physical Therapy Course at UNINOVE - São Paulo (SP), Brazil.

Correspondence to: Raquel Agnelli Mesquita Ferrari - Programa de Mestrado e Doutorado em Ciências da Reabilitação - UNINOVE - Rua Vergueiro, 249 - CEP: O1504-O01 - São Paulo (SP), Brasil - E-mail: raquel.mesquita@gmail.com

Presentation: Dec. 2012 - Accepted for publication: Feb. 2014 - Financing source: São Paulo Research Foundation (FAPESP) (2011/18592-6) and National Counsel of Technological and Scientific Development (CNPq) (473710/2011-0; 303662/2012-3) - Conflict of interests: nothing to declare. 
controles que somente foram induzidas à diferenciação, em todos os parâmetros avaliados. Em conclusão, o anabolizante decanoato de nandrolona, nas concentrações avaliadas, não foi capaz de alterar a viabilidade de células musculares C2C12 durante o processo de diferenciação.

Descritores I Anabolizantes; Atletas; Células Musculares; Nandrolona; Proliferação de Células; Diferenciação Celular.

RESUMEN I Se utilizan los anabolizantes, en particular por atletas con el objetivo de aumentar la masa muscular y mejoría del desempeño. Este estudio tuvo como objetivo evaluar el efecto del anabolizante Deca- Durabolin ${ }^{\circledR}$ sobre la viabilidad (proliferación) de las células satélites musculares C2C12 inducidas a la diferenciación, imitando el proceso de reparación tras una lesión. Las células fueron cultivadas en medio Eagle modificado por Dulbecco (DMEM) suplementado con 10\% de suero fetal bovino (SFB) y sometidas a diferenciación mediante la adición de 2\% de suero de caballo y, simultáneamente, incubadas con el anabolizante en las concentraciones de 5 , 10,25 y 50 M. En los grupos que no recibieron el anabolizante, ni el vehículo sirvió como controle. La viabilidad (proliferación) se evaluó después de uno, tres y cinco días, utilizando el método de MTT (3 - [4,5 - dimetiltriazol - 2 - il ] -2,5 difeniltetrazolio). Se realizaron tres experimentos independientes, en cada condición citada, y los resultados sometidos al análisis estadístico con nivel de significación de $\mathrm{p} \leq 0,05 \%$ (ANOVA/ Dunnett). Los resultados permitieron verificar que no hubo diferencia en la viabilidad entre células musculares tratadas con anabolizante e inducidas a diferenciación y culturas de controles que sólo fueron inducidas a diferenciación en todos los parámetros evaluados. En conclusión, el anabolizante decanoato de nandrolona, en las concentraciones evaluadas, no fue capaz de alterar la viabilidad de células musculares C2C12 durante el proceso de diferenciación.

Palabras clave I Anabolizantes; Atletas; Células Musculares; Nandrolona; Proliferación de la Célula; Diferenciación Celular.

\section{INTRODUCTION}

The endocrine system influences the muscle growth and development throughout life, and hormone excess or deficiency can affect the muscle structure and function ${ }^{1}$. Many studies conducted with animals demonstrate that androgens have positive effects on the increase of muscle mass and strength through androgen receptors $(\mathrm{AR})^{2}$ and on the determination of thin body mass ${ }^{3}$.

Therefore, the Androgenic Anabolic Steroids (AAS) are frequently used by athletes from several sports, with the objective of improving body mass and performance ${ }^{4}$. The prolonged use ${ }^{5}$ of this substance can often cause negative consequences to health, such as changes in reproduction, in the hepatic endocrine function and also in musculoskeletal characteristics ${ }^{4}$.

Nandrolone decanoate is a derivative of testosterone, and it is one of the most consumed AAS according to the National Institute on Drug Abuse (NIA) due to its moderate androgenic potential associated to its good anabolic properties. Nandrolone is influenced by the 5 $\alpha$-reductase enzyme, and it produces a metabolite with low-affinity for the receptor. Therefore, nandrolone itself interacts with the receptors for steroids, and produces relatively greater anabolic responses ${ }^{6}$. Some studies point out that nandrolone decanoate can modulate the regulation of the cell cycle, and, therefore, alter muscle mass, but intramuscular processes are not very clear yet ${ }^{7,8}$.
The skeletal muscle has the ability to respond to several stimuli, leading to a set of metabolic and morphological adaptations. This excellent capacity of muscle regeneration is attributed to the presence of myogenic precursor cells called Satellite Cells (SC), which are affected by several elements, such as mechanical stimulation, aging and endocrine factors 9

It is a known fact that $\mathrm{SC}$, in an injury situation, are activated and are then called myoblasts. These proliferate, become different and merge, generating myotubes that are attached to a pre-existing fiber, or form a new functional muscle fiber ${ }^{10-12}$. For that, a complex set of cell responses is activated, which leads to the proper regeneration of the injured tissue and to a well innervated muscle, which is vascularized and has an intact contractile system ${ }^{13}$. Therefore, the process of muscle repair is well described in literature, but its association with the use of anabolic steroids is not very clear.

Thus, due to the high incidence of injuries among athletes, it is essential to know the effects and consequences of the use of anabolic steroids during the process of repair, since its use is frequent to improve the sports performance. Therefore, this study conducted an in vitro assessment of the effect of the nandrolone (Deca-Durabolin ${ }^{\circledR}$ ), under different concentrations, concerning the viability of muscle satellite cells during the differentiation process. 


\section{METHODOLOGY}

\section{Cell culture}

The $\mathrm{C} 2 \mathrm{C} 12$ cell lineage used in this study is a subclone of the $\mathrm{C} 2$ myoblast line, which derives from the $\mathrm{SC}$ of adult mice, and presents most characteristics of normal muscle cells ${ }^{14-16}$. Cells were cultivated in the Dulbecco's Modified Eagle Medium (DMEM) (Cultilab, Campinas, SP, Brazil), with 10\% fetal bovine serum (FBS) (Cultilab, Campinas, SP, Brazil) and $1 \%$ antibiotic-antimycotic solution (Cultilab), being maintained in a $37^{\circ} \mathrm{C}$ stove, under a humid atmosphere with $5 \%$ of $\mathrm{CO}_{2}$. Cell growth was controlled every 24 hours, and when the cell monolayer became subconfluent for the continuation of the cell lineage, subcultivation was performed with PBS1X wash buffer $\left(\mathrm{NaCl} 140 \mathrm{mM}\right.$; KCl $2.5 \mathrm{mM} ; \mathrm{Na}_{2} \mathrm{HPO}_{4} 8 \mathrm{mM}$; $\mathrm{KH}_{2} \mathrm{PO} 1.4 \mathrm{mM}$; $\mathrm{pH} 7.4$ ) and trypsin solution. Cells were centrifuged at $1,200 \mathrm{rpm}$ and afterwards they were relifted in $1 \mathrm{~mL}$ of DMEM. The viability of cells was assessed by counting with Trypan blue vital staining (0.4\%). The cells used in the experiments were those with viability higher than $95 \%$. For the induction of differentiation, cells were maintained in DMDM with $2 \%$ horse serum ${ }^{17}$.

\section{Cell viability (proliferation) assay (MTT)}

Cell viability (proliferation) was assessed one, three and five days after incubation with nandrolone decanoate Deca-Durabolin ${ }^{\circledR}$ (Organon, Brasil) at the final concentrations of 5, 10, 25 and $50 \mu \mathrm{M}$ (Organon, Brasil) or the drug vehicle (1.5:1 - benzyl alcohol/peanut oil), added in different amounts according to the anabolic concentrations (vehicle 5, 10, 25 and $50 \mu \mathrm{M}$, respectively). Together with the treatment with the anabolic steroids, $2 \%$ horse serum was added (Invitrogen, Brazil) to the culture for the induction of differentiation of muscle cells ${ }^{17}$.

The methodology used to analyze cell viability is based on the ability of the mitochondrial dehydrogenase enzyme, found only in viable cells, in cleavage of the tetrazolium ring of the MTT method (3-[4,5- dimethylthiazol -2-il]-2,5 diphenyltetrazolium $)^{18,19}$, forming dark-blue formazan crystals, which are impermeable to cell membranes, therefore, they are retained inside the viable cells. The posterior cell lyses releases these formazan salts. The number of viable cells is directly proportional to the level of blue formazan crystals.

For this assay, $1 \times 10^{3}$ cells per well were used and added to the flat culture plates of 96 wells. They were sterile (Costar) and incubated at $37^{\circ} \mathrm{C}$ and $5 \%$ of $\mathrm{C}_{\mathrm{O} 2}$ during the different periods of incubation. After the end of the incubation period, wells were washed with PBS1X ( NaCl 140 mM; KCl 2.5 mM; $\mathrm{Na}_{2} \mathrm{HPO}_{4} 8 \mathrm{mM}$; $\mathrm{KH}_{2} \mathrm{PO} 1.4 \mathrm{mM}$; $\mathrm{pH} 7.4$ ) in order to remove the dead cells, and MTT was added $(0.5 \mu \mathrm{g} / \mathrm{mL})$ (3-(4,5-dimethylthiazol-2-yl)-2,5,-diphenyltetrazolium bromide) (Sigma-Aldrich, St. Louis, MO, USA). Cells were incubated for 4 hours at $37^{\circ} \mathrm{C}$ and $5 \%$ of $\mathrm{CO}_{2}$. Afterwards, isopropyl alcohol was added to solubilize the formed crystals. Finally, absorbance was read at $620 \mathrm{~nm}$ with the assistance of a plate reader (Anthos 2020, Anthos Labtec Instruments, Wals, Austria). All of the experiments were conducted three times, independently, and each sample was analyzed four times.

\section{Statistical analysis}

Groups were compared by the analysis of variance (ANOVA). The Dunnett's test was used to determine significant differences between experimental groups and the control group. Values of $\mathrm{p} \leq 0.05$ were considered to be statistically significant. Data were analyzed by the software GraphPad Prism 4.0 (GraphPad Software, San Diego, CA, USA).

\section{RESULTS}

According to the results, there was no significant difference in cell viability and proliferation, assessed by the MTT method, between muscle cells treated with anabolic steroids and control cells (Figure 1) in all of the evaluated periods. Results for the vehicle were similar to control (data not shown).

Results also demonstrated there has been increased cell viability (proliferation) after three and five days, when compared to the one day period, and that there was no increase in viability (proliferation) between the groups five and three days, which confirms cell differentiation in this period (Figure 1). 


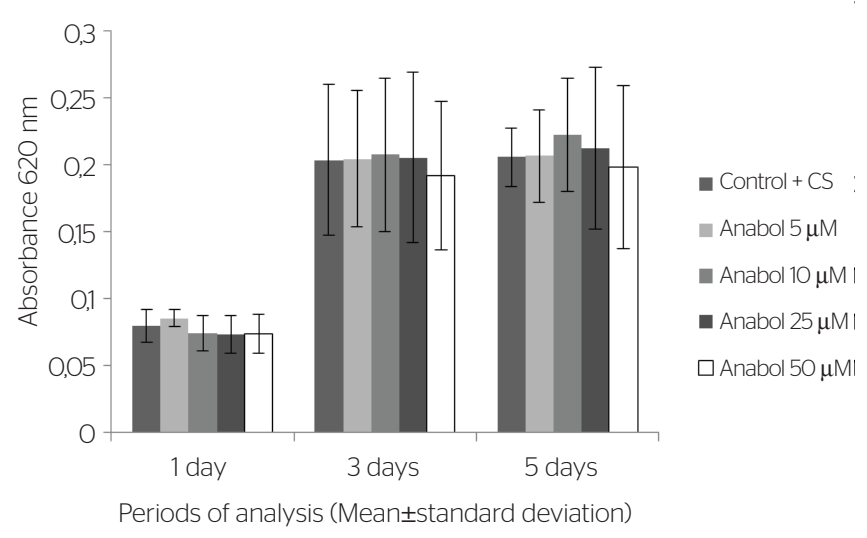

Figure 1. In vitro evaluation of cell viability (proliferation) of satellite muscle cells treated with nandrolone decanoate in different concentrations and submitted to the induction of the differentiation process

\section{DISCUSSION}

In vivo studies demonstrate that the effects of nandrolone decanoate depended on the assessed muscles, time of treatment, dose and association or not with exercises. All of these were able to cause increased muscle mass ${ }^{8,20-22}$, alterations in the cell cycle ${ }^{7}$, bone mineral density $^{23}$, bone growth ${ }^{24}$, and the ARs influence these effects $^{8,25}$. The question is if there is interference of nandrolone decanoate on viability (proliferation) of muscle cells and muscle repair.

In response to AAS, there is increasing intracellular calcium $\left(\mathrm{Ca}^{2+}\right)$ in a series of cell types, including osteoblasts, platelets, muscle cells, heart myocytes and neurons. In heart cells, for instance, testosterone promotes heart hypertrophy; as to neurons, depending on the concentration, testosterone can cause neuronal apoptosis ${ }^{26}$.

Kamanga-Sollo et al. ${ }^{27}$ studied the culture of Bovine Satellite Cells (BSC) treated with androgens and observed that the treatment of BSC cultures increased mRNA IGF-I expression and proliferation, thus establishing that steroids have direct anabolic effects. Sculthorp et al. ${ }^{28}$ investigated the IGF-1 and the mRNA IGF-1 expressions, maintaining the IGF-I as a central mediator in cell pathways associated with muscle hypertrophy. This shows the relationship of androgens with muscle growth and differentiation. However, in these findings, nandrolone decanoate did not change the proliferation of muscle cells in differentiation process.

Diel et al. ${ }^{1}$ showed that the essential differentiation mechanisms are modulated by androgens, and that they stimulate the proliferation of $\mathrm{C} 2 \mathrm{C} 12$ cells, accelerate the differentiation process for myotubes and stimulate myostatin expression in non-differentiated and differentiated cells. However, they used the induction of differentiation with 3\% horse serum and another type of anabolic steroid, the dihydrotestosterone (DHT), by assessing the activity of $\mathrm{CK}$ and the proliferation after one, three and six days, which is different from this study and makes it difficult to compare the results.

Nogueira et al. ${ }^{29}$ assessed the effect of nandrolone decanoate over osteoblasts after irradiation with low potency laser and showed reduced viability (proliferation) in concentrations of 10,25 and $50 \mu \mathrm{M}$, as well as increased adhesion after 60 minutes in contractions of 5,10 and $25 \mu \mathrm{M}$; however, the combined effect of these therapies and the different cell types do not allow the direct comparison with the findings in this study, but it demonstrates the regulating role of this steroid over cell proliferation.

\section{CONCLUSION}

The anabolic steroid nandrolone decanoate (DecaDurabolin $\left.{ }^{\circledR}\right)$, with the used concentrations, was not able to change the viability of muscle cells during the in vitro differentiation process. New studies are necessary to better understand other possible effects of nandrolone decanoate over these cells, such as the regulation of myogenic regulatory factors involved in the proliferation and differentiation processes. This knowledge will assist the understanding of how anabolic steroids can influence the muscle repair process, especially with regard to individuals who use this type of substance.

\section{REFERENCES}

1. Diel P, Baadners D, Schlupmann K, Velders M, Schwarz JP. C2C12 myoblastoma cell differentiation and proliferation is stimulated by androgens and associated with a modulation of myostatin and Pax7 expression. J Mol Endocrinol. 2008;40(5):231-41.

2. Chen Y, Zajac D, MacLean HE. Androgen regulation of satellite cell function. J Endocrinol. 2005;186(1):21-31.

3. Vlahopoulos S, Zimmer WE, Jenster G, Belaguli NS, Balk SP, Brinkmann $\mathrm{AO}$ et al. Recruitment of the androgen receptor via serum response factor facilitates expression of a myogenic gene. J Biol Chem. 2005;280(9):7786-92. 
4. D’Ascenzo S, Millimaggi D, Di Massimo C, Saccani-Jotti G, Botre F, Carta $\mathrm{G}$ et al. Detrimental effects of anabolic steroids on human endothelial cells. Toxicol Lett. 2007:169(2):129-36.

5. Marqueti RC, Parizotto NA, Chriguer RS, Perez SEA, Selistrede-Araujo HS. Androgenic-anabolic steroids associated with mechanical loading inhibit matrix metallopeptidase activity and affect the remodeling of the achilles tendon in rats. Am J Sports Med. 2006;34(8):1274-80.

6. Silva PRP, Danielski R, Czepielewski MA. Esteróides anabolizantes no esporte. Rev Bras Med Esporte. 2002;8(6):235-43.

7. McClung JM, Mehl KA, Thompson RW, Lowe LL, Carson JA. Nandrolone decanoate modulates cell cycle regulation in functionally overloaded rat soleus muscle. Am J Physiol Regul Integr Comp Physiol. 2005;288(6):R1543-52.

8. Diel P, Friedel A, Geyer H, Kamber M, Laudenbach-Leschowsky $U$, Schänzer $W$ et al. The prohormone 19-norandrostenedione displays selective androgen receptor modulator (SARM) like properties after subcutaneous administration. Toxicol Lett. 2008:177(3):198-204.

9. Zammit PS. All muscle satellite cells are equal, but are some more equal than others? J Cell Sci. 2008;121(Pt 18):2975-82.

10. Tidball JG. Inflammatory processes in muscle injury and repair. Am J Physiol Regul Integr Comp Physiol. 2005;288(2):R345-53.

11. Kook SH, Lee HJ, Chung WT, Hwang IH, Lee SA, Kim BS et al. Cyclic mechanical stretch stimulates the proliferation of $\mathrm{C} 2 \mathrm{C} 12$ myoblasts and inhibits their differentiation via prolonged activation of p38 MAPK. Mol Cells. 2008;25(4):479-86.

12. Stuelsatz P, Pouzoulet F, Lamarre Y, Dargelos E, Poussard S, Leibovitch S et al. Down-regulation of myod by calpain 3 promotes generation of reserve cells in C2C12 myoblasts. J Biol Chem. 2010;285(17):12670-83.

13. Charge SBP, Rudnicki MA. Cellular and molecular regulation of muscle regeneration. Physiol Rev. 2004;84(1):209-38.

14. Yaffe D, Saxel D. Serial passaging and differentiation of myogenic cells isolated from dystrophic mouse muscle. Nature. 1977;270(5639):725-7.

15. Lai J, Pittelkow MR. Physiological effects of ultrasound mist on fibroblast. Int J Dermatol. 2007;46(6):587-93.

16. Hill GE, Fenwick S, Matthews BJ, Chivers RA, Southgate J. The effect of low-intensity pulsed ultrasound on repair of epithelial cell monolayers in vitro. Ultrasound Med Biol. 2005;31(12):1701-6.

17. Artilheiro PP, Fernandes KPS, Barbosa JLP, de Oliveira TS, Bussadori SK, Mesquita-Ferrari RA. Análise comparativa dos efeitos do ultrassom terapêutico e laser de baixa potência sobre a proliferação de células musculares durante a diferenciação celular. Fisioter Mov. 2012;25(1):21-9
18. Mosmann T. Rapid colorimetric assay for cellular growth and survival: application to proliferation and cytotoxicity assays. J Immunol Methods. 1983;65(2):55-63.

19. Woerdenbag HJ, Merfort I, Passreiter CM, Schmidt TJ, Willuhn G, van Uden W et al. Cytotoxicity of flavonoids and sesquiterpene lactones from Arnica species against the GLC4 and the COLO 320 cell lines. Planta Med. 1994;60(5):434-7.

20. Lewis MI, Fournier M, Yeh AY, Micevych PE, Sieck GC. Alterations in diaphragm contractility after nandrolone administration: an analysis of potential mechanisms. J Appl Physiol. 1999;86(3):985-92.

21. Johansen KL, Painter PL, Sakkas GK, Gordon P, Doyle J, Shubert T. Effects of resistance exercise training and nandrolone decanoate on body composition and muscle function among patients who receive hemodialysis: a randomized, controlled trial. J Am Soc Nephrol. 2006:17(8):2307-14.

22. Lee DK. Androgen receptor enhances myogenin expression and accelerates differenciation. Biochem Biophys Res Commun. 2002;294(2):408-13.

23. Frisoli, Jr A, Chaves PHM, Pinheiro MM, Szejnfeld VL. The Effect of nandrolone decanoate on bone mineral density, muscle mass, and hemoglobin levels in elderly women with osteoporosis: a doubleblind, randomized, placebo-controlled Clinical Trial. J Gerontol A Biol Sci Med Sci. 2005;60A(5):648-53.

24. Gebhardt A, Pancherz H. The effect of anabolic steroids on mandibular growth. Am J Orthod Dentofacial Orthop. 2003;123(4):435-40.

25. Sinha-Hikim I, Roth SM, Lee MI, Bhasin S. Testosterone-induced muscle hypertrophy is associated with an increase in satellite cell number in healthy, young men. Am J Physiol Endocrinol Metab. 2003:285:E197-E205.

26. Vicencio JM, Estrada M, Galvis D, Bravo R, Contreras AE, Rotter D et al. Anabolic androgenic steroids and intracellular calcium signaling: a mini review on mechanisms and physiological implications. Mini Rev Med Chem. 2011:11(5):390-8.

27. Kamanga-Sollo E, White ME, Hathaway MR, Chung KY, Johnson BJ, Dayton WR. Roles of IGF-I and the strogen, androgen and IGF-I receptors in stradiol-17beta and trenbolone acetate-stimulated proliferation of cultured bovine satellite cells. Domest Anim Endocrinol. 2008;35(1):88-97.

28. Sculthorpe N, Solomon AM, Sinanan AC, Bouloux PM, Grace F, Lewis MP. Androgens affect myogenesis in vitro and increase local IGF-1 expression. Med Sci Sports Exerc. 2012;44(4):610-5.

29. Nogueira GT, Mesquita-Ferrari RA, Souza NHC, Artilheiro PP, Albertini R, Bussadori SK et al. Effect of low-level laser therapy on proliferation, differentiation, and adhesion of steroid-treated osteoblasts. Lasers Med Sci. 2012;27:1189-93. 